\title{
Determination of Lactic Acid Bacteria Viability in the Small Intestine of Catfish (Pangasius djambal) by Using the ${ }^{32} \mathrm{P}$ Radioisotope
}

\author{
I. Sugoro $^{1^{\star}}$, D. Fairuz ${ }^{2}$, A. Citraresmini ${ }^{1}$ and A.P. Murni ${ }^{1}$ \\ ${ }^{1}$ Center for Isotopes and Radiation Application, National Nuclear Energy Agency, \\ Jl. Lebak Bulus Raya No.49, Jakarta 12070, Indonesia \\ ${ }^{2}$ Departement of Biology, Faculty of Science and Technology UIN Syarif Hidayatullah, \\ Jl. Ir. H. Djuanda No.95, Ciputat, Tangerang Selatan 15412, Indonesia
}

\section{ARTICLE INFO}

\section{Article history:}

Received 04 October 2014

Received in revised form 26 March 2015

Accepted 05 April 2015

\section{Keywords:}

Catfish

Viability

Probiotic

Lactic acid bacteria

Radioisotope ${ }^{32} \mathrm{P}$

\begin{abstract}
A B S T R A C T
The viability of probiotics is important to be determined, as is its probiotic potency in the small instestine of fish. The result can be used as a basis to determine the feeding frequency of the probiotics to the fish.The aim of this study is to gain information about the viability of lactic acid bacteria (LAB) in the small intestine of fish by using the ${ }^{32} \mathrm{P}$ isotope technique. Catfish (Pangasius djambal) was used as a test fish, and the LAB with the code of P2.1 PTB was the subject of the experiment. Before its viability was tested, the LAB had been labelled with radioisotope ${ }^{32} \mathrm{P}$, then mixed into catfish feed. Its viability could be determined by counting the activity of ${ }^{32} \mathrm{P}$. The results showed that the percentage of LAB viability in the small intestine of catfish declined until day 7. The percentage of LAB viability was decreased at an amount of $30 \%$ at day 3 . Based on this result, the feeding frequency of LAB P2.1 PTB is every 3 days.
\end{abstract}

\section{INTRODUCTION}

The role of probiotics and their mechanism of action in aquaculture are continuously being researched and developed. This is due to their potency to improve the quantity and quality of aquaculture production. Probiotics are living microorganisms which provide health benefit to the host when taken in sufficient quantities [1]. The benefits of probiotics for aquaculture are improvements on the immune system [2], feed efficiency and protein retention, [3] and growth rate [4].

One of the requirements for microorganisms to be used as probiotics is the ability to colonize the intestinal epithelial cells, thus preventing or reducing colonization by pathogenic microorganisms [5]. Research on the application of

* Corresponding author.

E-mail address:irawans@batan.go.id

DOI: http://dx.doi.org/10.17146/aij.2015.352 probiotics to fish in general is still centered on its abilities to increase the growth rate of fish, control disease, enhance immune response, provide nutritional and enzymatic contributions to the digestion of the host, and improve water quality. However, researches about the viability of probiotics in the digestive tract of its host are still rarely conducted. The ability of microorganisms to colonize the host's digestive tract can be determined by the viability test using a radioisotope tracer compound. The radioisotope used in this study is phosporus-32 $\left({ }^{32} \mathrm{P}\right) .{ }^{32} \mathrm{P}$ is unique in its being used both as a label and as a radiation source; therefore, those ${ }^{32} \mathrm{P}$ compounds can be used as tracer in molecular biology experiments in animals, plants and bacteria [6]. Phosphorus-32 is a beta emitter $(1.71 \mathrm{MeV})$ with a half-life of 14.3 days which is able to replace the phosphorus in compounds which comprise cellular components, such as cell membranes, RNA, DNA, and ATP which functions as a cell's energy source $[7,8]$. This characteristic 
facilitates binding between ${ }^{32} \mathrm{P}$ in its compounds with microorganism cells in the viability test.

This study aims to determine the viability of lactic acid bacteria (LAB) in the small intestine of catfish to gain empirical data about its potency as probiotics. The results of viability test can also be used as a basis to determine the feeding frequency of probiotic when applied to fish. A lactic acid bacteria strain with the code of P2.1 PTB was used in this experiment. This bacterium was isolated from catfish intestine [9].

\section{EXPERIMENTAL METHODS}

\section{Growth curve analysis}

A lactic acid bacteria strain was inoculated into nutrient broth (NB) media in the Erlenmeyer flask. The cultures were incubated with a shaker incubator for $0,2,4,8,12,18,24$, and 30 hours for the measurement of the number of cells using spectrophotometer $\left(\lambda_{600 \mathrm{~nm}}\right)$ and the $\mathrm{pH}$ of the media.

\section{Measurement of ${ }^{32} \mathrm{P}$ incorporation percentage}

The measurement of the incorporation percentage was performed at the same time as the measurement of growth curve. A $100 \mu \mathrm{L}$ sample of ${ }^{32} \mathrm{P}\left(\mathrm{KH}_{2}{ }^{32} \mathrm{PO}_{4} ; 10 \mathrm{mCi}\right)$ was mixed into each of Erlenmeyer flask which also contained $\mathrm{NB}$ and LAB. Each Erlenmeyer flask was coded and was incubated using shaker incubator for $0,2,4,8,12$, 18, 24, and 30 hours. From each isolate in NB media, $5 \mathrm{ml}$ was taken and transferred into a tube. Each sample tube was centrifuged at $10,000 \mathrm{rpm}$ and then twice rinsed with distilled water. The supernatant was separated to measure its activity with a liquid scintillation counter (LSC). The incorporation percentage was determined by using the following formula:

$$
\% \text { incorporation }=(\mathrm{A}-\mathrm{B}) / \mathrm{A} x(100 \%)
$$

Notes:

A : activity of ${ }^{32} \mathrm{P}$ in media on day $0(\mathrm{cpm})$

$\mathrm{B}:$ activity of ${ }^{32} \mathrm{P}$ in media on day $\mathrm{t}(\mathrm{cpm})$

\section{Determination of viability using ${ }^{32} \mathrm{P}$}

Lactic acid bacteria culture with the highest $\%$ incorporation in NB medium was inoculated into $100 \mathrm{ml}$ of NB medium. $100 \mu \mathrm{L}$ of ${ }^{32} \mathrm{P}$ was added and subsequently incubated at room temperature with $120 \mathrm{rpm}$ agitation until the peak time of incorporation. Afterward, the supernatant and the pellets of LAB culture were separated (precipitated) by centrifugation at $10,000 \mathrm{rpm}$ at a temperature of $4^{0} \mathrm{C}$, then rinsed with distilled water twice. The pellet was diluted again with distilled water and mixed with the feed. This mixture was left for two hours. The pellets were inserted into an aquarium which already contained 20 catfish with lengths of $16-19 \mathrm{~cm}$. The proportion of feed given was $3 \%$ of fish's body weight/fish. Observations were conducted on days $0,1,3,7$, and 14. Each sampling was taken on 3 fish.

Bacterial viability was determined by detecting the presence of LAB-labelled ${ }^{32} \mathrm{P}$ in the small intestine. It was cut from the end of the ventriculus to the base of the large intestine and the sample was soaked in $5 \mathrm{ml}$ of $\mathrm{HCl} 35 \%$. The mixture was homogenized with a vortex mixer and centrifuged at a speed of $5000 \mathrm{rpm}$. The activity of the supernatant was measured with a liquid scintillation counter. The viability of the bacteria was determined by using the following formula:

$$
\% \text { viability }=\mathrm{A} / \mathrm{B} x(100 \%)
$$

Notes:

A : activity on day $\mathrm{t}(\mathrm{cpm})$

$\mathrm{B}:$ activity on day $0(\mathrm{cpm})$

\section{RESULTS AND DISCUSSION}

\section{Growth curve}

The growth curve of LAB showed that there is no adaptation phase in its growth (Fig. 1). The bacteria directly entered exponential phase. It is possible that the use of the same media as inoculum and growth culture allowed the adaptation to be completed in a shorter time. After 12 hours, the bacteria entered the stationary phase until the end of incubation (30 hours) but the decline or death phase had not occured.

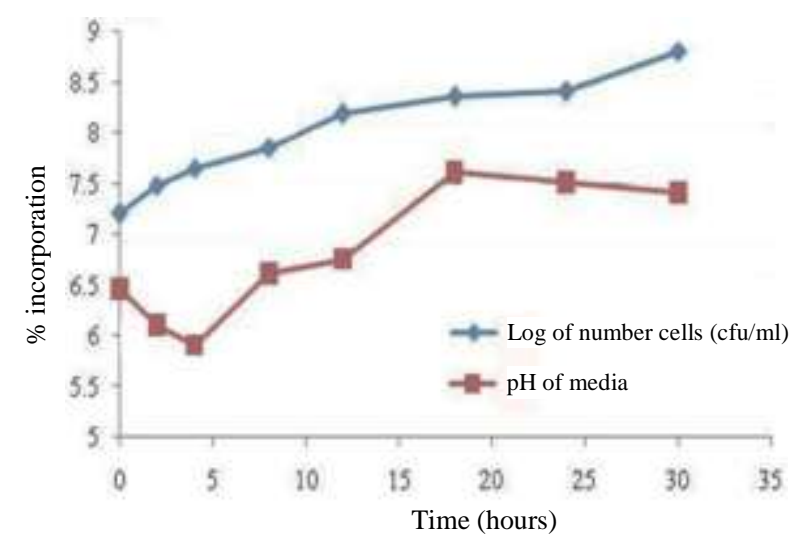

Fig. 1. Comparison of cell growth with $\mathrm{pH}$ value. 
During the bacteria growth, the $\mathrm{pH}$ of media decreased until 4 hours of incubation. Afterward, the $\mathrm{pH}$ increased until 18 hours. It indicates that the bacteria utilized the nutrition in the media. Acidic condition may have occurred because of degradation of organic compounds, producing volatile fatty acids such as acetic, lactic, and propionic acids. The degradation of proteins such as peptone, meat extract and yeast extract, which was contained in $\mathrm{NB}$, produced ammonia; this have caused basic conditions in media [10]. The $\mathrm{pH}$ value strongly affects the metabolism of bacteria, especially the enzyme rate [11].

\section{${ }^{32} \mathrm{P}$ incorporation percentage}

The ${ }^{32} \mathrm{P}$ incorporation percentage in bacteria cell increased during incubation (Fig. 2). The highest incorporation percentage occurred at hour 12 of incubation. This incubation time can be used as a reference for further studies to measure cell viability in the catfish intestine.

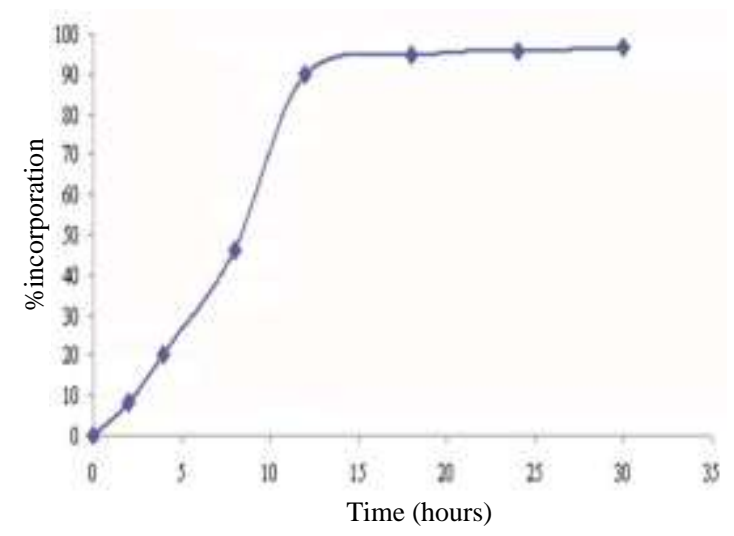

Fig. 2. ${ }^{32} \mathrm{P}$ incorporation percentage in bacteria cells.

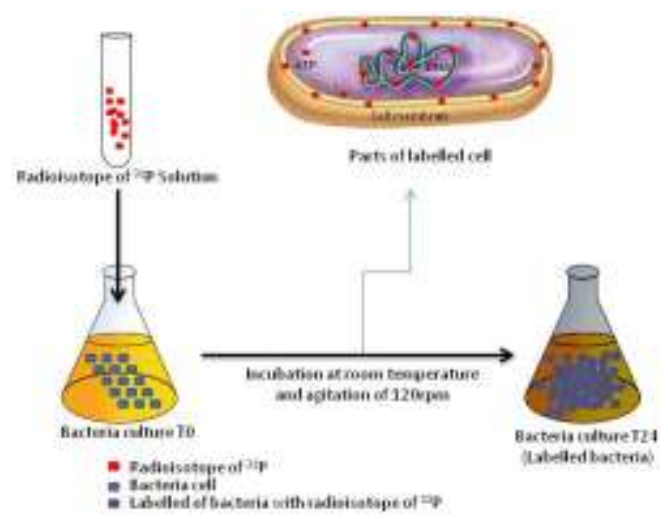

Fig. 3. Mechanism of bacteria labeling by radioisotope ${ }^{32} \mathrm{P}$.

The pattern of the curve of the incorporation percentage showed similarity with the pattern of the growth curve (Fig. 1). It was suspected that during the division, the incorporated ${ }^{32} \mathrm{P}$ radioisotope became part of cell components such as DNA, membrane and ATP (Fig. 3). This isotope could only be absorbed when the cells are still alive and continually dividing. When the cells die, the phosphorous will be released back into the media and absorbed again by the living cells.

\section{Determination of LAB viability}

The percentage of LAB viability in the small intestine of catfish declined until the $7^{\text {th }}$ day (Fig. 4). The percentage of LAB viability decreased to less than $30 \%$ at day 3 . If the number of LAB cells decreased, it will affect the performance of probiotic for the fish growth rate. We expect the LAB's probiotic function to not be exhausted in the gut.

The occurence of this condition could be due to the excretion of bacteries with the feces, rendering only a small number able to form colonies. It can be shown that until day 7 , the viability of LAB was $5 \%$. Another possibility is the bacteria died because they lost the ability to compete with indigenous bacteria [12]. Further results showed that these isolates were able to survive and colonize the small intestine of catfish.

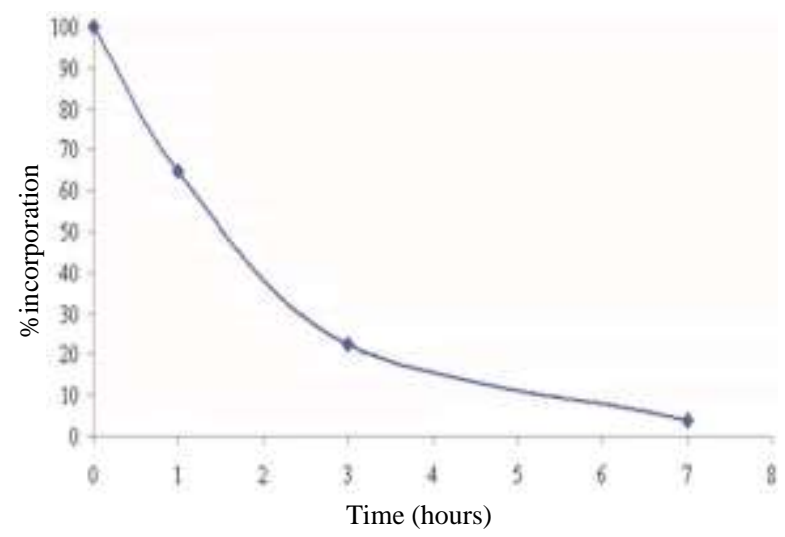

Fig. 4. Viability of LAB in the small intestine of catfish as determined by using the ${ }^{32} \mathrm{P}$ radioisotope.

The description of how the bacteria could be viable can be seen in the Fig. 5. The mix of labeled LAB and feed was given to the fish. Afterward, there are two possibilities for the labeled bacteria, i.e. colonizing the intestine surface and growth or getting excreted along with feces. The LAB have the ability to colonize the epithelial layer of intestine and live with other bacteria [13]. 


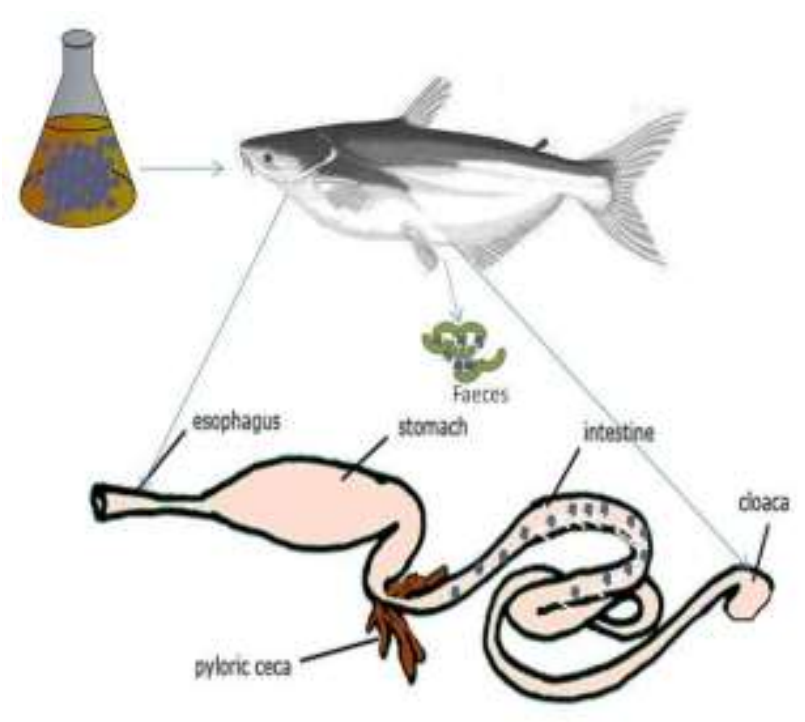

Fig. 5. Viability of ${ }^{32} \mathrm{P}$-labelled cells in fish.

Research by Dyvia et al. [14] revealed that the probiotic was able to live and significantly reduce the amount of pathogenic bacteria in the intestine of Puntius conchonius larvae. Vine et al. [15] examined, in vitro, the competition between 5 candidates of probiotic bacteria and 2 pathogenic bacteria to attach to the intestinal mucus of fish.

The results of this study showed that isolates of LAB with code P2.1 PTB have a potential to become a probiotic candidate. In addition, the decrease of LAB viability on day 3 could become the reference for the feeding frequency. It could be done once every three days. The application LAB based on the viability data in the small intestine is useful for the reduction in production costs due to administering the probiotics every day.

\section{CONCLUSION}

The viability of lactic acid bacteria (LAB) could be determined by using the radioisotope ${ }^{32} \mathrm{P}$ radioisotope. The frequency of feeding LAB with code P2.1 PTB to the fish is once every three days

\section{REFERENCES}

1. Anonymous, Report of A Joint FAO NHO Expert Consultation on Evaluation of Health and Nutritional Properties of Probiotics in Food Including Powder Milk with Live Lactic Acid Bacteria, FAO/WHO, Vienna (2001) 3.

2. Septiarini, E. Harpeni and Wardiyanto, E-Journal of Engineering and Technology Aquaculture 1 (2012) 39. (in Indonesian)

3. J.E. Setiawati, Tarsim, Y.T. Adiputra, et al., E-Journal Engineering and Technology Aquaculture 1 (2013) 151. (in Indonesian)

4. D. Jusadi, E. Gandara and I. Mokoginta, Journal of Indonesian Aquaculture 3 (2004) 15. (in Indonesian)

5. J.L. Balcazar, I.D. Blas, I. Ruiz-Zarzuela, et al., Veterinary Microbiology 114 (2006) 173.

6. T.N. Tuan, P.M. Duc and K. Hatai, International Journal of Research in Fisheries and Aquaculture 3 (2013) 89.

7. A.N.H. Creager, Studies in History and Philosophy of Biological and Biomedical Sciences 40 (2009) 29.

8. A. Wyttenbach and A.M. Tolkovsky, Mol. Cell. Proteomics 5 (2006) 553.

9. S. Purnami, M. Syaifudin and Giyatmi, Journal of Food and Nutrition 3 (2009) 11. (in Indonesian)

10. D. Hanifa, N. Fitriana, A.P. Murni et al., Proceeding of The annual meeting of the faculty of mathematics and natural science Graduate (2014) 203.

11. M.J. Pelczar and E.C.S. Chan, Basic of Microbiology 1, Translators: R.S. Hadioetomo, T. Imas, S.S. Tjitrosomo dan S.L. Angka, UI Press, Jakarta (2005) 85.

12. Alberts, B.D. Bray, K. Hopkin, et al., Essential Cell Biology, Garland Publishing, Munich (2009) 224.

13. M.I. Effendi, Biology of Fishery, Pustaka Nusatama, Yogyakarta. (2002) 163. (in Indonesian)

14. K.R. Divya, A. Isamma, V. Ramasubramanian, et al., J. Environ. Biol. 33 (2012) 551.

15. N.G. Vine, W.D. Leukes, H. Kaiser, et al., Journal of Fish Diseases 27 (2004) 319. 